\title{
Article \\ Comparative Assessment of Phytochemical Compounds and Antioxidant Properties of Kernel Oil from Eight Sour Cherry (Prunus cerasus L.) Cultivars
}

\author{
Małgorzata Stryjecka ${ }^{1}$, Monika Michalak ${ }^{2, * \mathbb{D}}$, Jacek Cymerman ${ }^{1}$ and Anna Kiełtyka-Dadasiewicz ${ }^{3, *(\mathbb{D})}$ \\ 1 Institute of Agricultural Sciences, State School of Higher Education Chełm, 22-100 Chełm, Poland; \\ mstryjecka@pwszchelm.edu.pl (M.S.); jcymerman@pwszchelm.edu.pl (J.C.) \\ 2 Department of Dermatology, Cosmetology and Aesthetic Surgery, Collegium Medicum, \\ Jan Kochanowski University, 25-369 Kielce, Poland \\ 3 Department of Plant Production Technology and Commodity Science, University of Life Sciences, \\ 20-950 Lublin, Poland \\ * Correspondence: monika.michalak@ujk.edu.pl (M.M.); anna.kieltyka-dadasiewicz@up.lublin.pl (A.K.-D.)
}

check for

updates

Citation: Stryjecka, M.; Michalak, M.; Cymerman, J.; Kiełtyka-Dadasiewicz, A. Comparative Assessment of Phytochemical Compounds and Antioxidant Properties of Kernel Oil from Eight Sour Cherry (Prunus cerasus L.) Cultivars. Molecules 2022, 27,696. https://doi.org/10.3390/ molecules27030696

Academic Editor: Maria Atanassova

Received: 29 December 2021

Accepted: 19 January 2022

Published: 21 January 2022

Publisher's Note: MDPI stays neutral with regard to jurisdictional claims in published maps and institutional affiliations.

Copyright: (C) 2022 by the authors. Licensee MDPI, Basel, Switzerland. This article is an open access article distributed under the terms and conditions of the Creative Commons Attribution (CC BY) license (https:// creativecommons.org/licenses/by/ $4.0 /)$.

\begin{abstract}
New plant oils as a potential natural source of nutraceutical compounds are still being sought. The main components of eight cultivars ('Koral', 'Lucyna', 'Montmorency', 'Naumburger', 'Wanda', 'Wigor', 'Wołyńska', and 'Wróble') of sour cherry (Prunus cerasus L.) grown in Poland, including crude fat, protein, and oil content, were evaluated. The extracted oils were analysed for chemical and biological activity. The oils had an average peroxide value of $1.49 \mathrm{mEq} \mathrm{O}_{2} / \mathrm{kg}$, acid value of 1.20 $\mathrm{mg} \mathrm{KOH} / \mathrm{g}$, a saponification value of $184 \mathrm{mg}$ of $\mathrm{KOH} / \mathrm{g}$, and iodine value of $120 \mathrm{~g} \mathrm{I}_{2} / 100 \mathrm{~g}$ of oil. The sour cherry oil contained linoleic (39.1-46.2\%) and oleic (25.4-41.0\%) acids as the major components with smaller concentrations of $\alpha$-eleostearic acid (8.00-15.62\%), palmitic acid (5.45-7.41\%), and stearic acid (2.49-3.17\%). The content of sterols and squalene varied significantly in all the studied cultivars and ranged between 336-973 mg/100 $\mathrm{g}$ and $66-102 \mathrm{mg} / 100 \mathrm{~g}$ of oil. The contents of total tocochromanols, polyphenols, and carotenoids were 119-164, 19.6-29.5, and 0.56-1.61 mg/100 g oil, respectively. The cultivar providing the highest amounts of oil and characterised by the highest content of PUFA (including linoleic acid), plant sterols, $\alpha$-and $\beta$-tocopherol, as well as the highest total polyphenol and total carotenoids content was been found to be 'Naumburger'. The antioxidant capacity of sour cherry kernel oils, measured using the DPPH ${ }^{\bullet}$ and ABTS ${ }^{\bullet+}$ methods, ranged from 57.7 to 63.5 and from 38.2 to $43.2 \mathrm{mg}$ trolox/100 g oil, respectively. The results of the present study provide important information about potential possibilities of application of Prunus cerasus kernel oils in cosmetic products and pharmaceuticals offering health benefits.
\end{abstract}

Keywords: Prunus cerasus; sour cherry oil; fatty acids; phytochemicals; antioxidants

\section{Introduction}

Plant oils are an important part of human diet, but also an essential ingredient of many cosmetic and pharmaceutical products. The nutritional and technological value of oils is determined mainly by the composition of fatty acids, but also by the content of substances, such as polyphenols, tocopherols, and carotenoids. Plant oils, including oils from fruit seeds, rich in biological compounds, exert beneficial effects on the human body (improved wellbeing and health status, reduced risk of diseases, e.g., cardiovascular diseases, neurological disorders, certain cancers, obesity, or type 2 diabetes) and significantly affect the proper appearance and function of the skin [1-3]. The above properties of plant-derived oils rich in health-enhancing compounds are associated, inter alia, with their ability of scavenging free radicals [4]. The pharmaceutical and cosmetic industries are looking for innovative sources of functional bio-oils rich in bioactive compounds. The presence of phytochemicals and nutraceuticals in sour cherry fruit justifies further use 
of kernels from Prunus cerasus L. species to produce oils for food, pharmaceutical, and cosmetic applications $[5,6]$.

The sour cherry (Prunus cerasus L.) belonging to the Rosaceae family, is a species cultivated in many regions of the world due to its fruits that are of great importance in the food industry for the production of juices, jams, and frozen food [6]. Poland is a leading producer of cherry fruits for consumption (a total of over 270,000 tons in 2017 and 2018) and is ranked fourth in the world after Russia, Turkey, and Ukraine [7]. The cherry fruit processing generates significant amounts of wastes (seeds) that can be used for oil production. For this purpose, however, the data on oil efficiency and quality are needed. Preliminary data of other authors inspire to obtain oil also from cherry cultivars growing in Poland. Górnaś et al. [8] have described the differences in the yield and quality of oil from cherry seeds of different cultivars. In the present study, the cultivars grown in the largest quantities for industrial purposes in Poland, i.e., 'Koral', 'Lucyna', 'Montmorency', 'Naumburger', 'Wanda', 'Wigor', 'Wołyńska', and 'Sparrows', were examined and described. The inedible residue of cherry fruit processing is a pit containing the oil, which is a rich source of polyunsaturated and monounsaturated fatty acids, as well as lipophilic compounds, such as carotenoids, tocochromanols, phytosterols, and squalene, showing considerable beneficial health effects $[2,5,8]$. Literature data indicate that the content of active ingredients in sour cherry kernel oils depends on cultivars and agro-climatic conditions $[2,5]$. The studies in this area are rather limited and concern sour cherry cultivars from Hungary [9], Romania [10], Greece [11], Italy [2], Turkey [5,12,13], Iran [6], and the USA [14]. Considering the growing interest in sour cherry-based products, it is essential to increase our knowledge of the chemical composition and biological activity of kernel oil from various $P$. cerasus $L$. cultivars. Therefore, the aim of the present study was to examine the main components (crude fat, protein, and oil) of kernels from eight cultivars of sour cherry (P. cerasus L.) grown in Poland. Moreover, the physicochemical properties of the sour cherry kernel oil, including acid value, peroxide value, saponification value, iodine value, fatty acid composition, content of sterols, and squalene, were determined. In addition, tocopherols and tocotrienols, total carotenoid, and total polyphenol content, as well as antioxidant activity $\left(\mathrm{DPPH}^{\bullet}\right.$ and $\mathrm{ABTS}^{\bullet+}$ ) were comprehensively investigated.

\section{Results and Discussion}

\subsection{Sour Cherry Kernel Properties}

The content of crude fat and crude protein in kernel of eight sour cherry cultivars was analysed. The inter-cultivar differences were slight (Table 1). The mean crude fat and crude protein content of sour cherry kernel were 41.3 and $31.3 \%$, respectively. The results obtained for the content of crude protein were generally consistent with those reported by Kazempour-Samak et al. [6] 29.3\% and Lazos [11] 25.3\% [11]. P. cerasus kernels were found to be rich in oil (31.6\%, on average); however, the differences for individual cultivars were noticeable. According to another study, the sour cherry kernel contained 36.1 [13], 31.89 [6], 26.0 [11], 22.5 [10], and $17.0 \%$ [12] of oil.

As shown in Table 1, the highest amount of oil was found in 'Naumburger' (35.4\%), while the lowest content was detected in 'Koral' (24.6\%). According to the results of another study, the oil content in different sour cherry cultivars grown in Poland, including 'Haritonovskaya', 'Latvijas Zemais', 'Shokoladnica', and 'Zentenes', was 37.1, 36.2, 36.6, and $35.2 \%$, respectively [8]. 
Table 1. The main components of sour cherry kernels of eight cultivars.

\begin{tabular}{cccc}
\hline \multirow{2}{*}{ Cultivar } & \multicolumn{3}{c}{ Components } \\
\cline { 2 - 4 } & Crude Fat (\%) & Crude Protein (\%) & Oil (\%) \\
\hline 'Koral' & $41.3^{\mathrm{C}}$ & $31.6^{\mathrm{AB}}$ & $24.6^{\mathrm{F}}$ \\
'Lucyna' & $40.9^{\mathrm{D}}$ & $31.4^{\mathrm{BC}}$ & $31.1^{\mathrm{D}}$ \\
'Montmorency' & $41.8^{\mathrm{A}}$ & $31.7^{\mathrm{A}}$ & $32.5^{\mathrm{C}}$ \\
'Naumburger' & $41.6^{\mathrm{B}}$ & $30.9^{\mathrm{E}}$ & $35.4^{\mathrm{A}}$ \\
'Wanda' $^{\mathrm{C}}$ & $41.3^{\mathrm{C}}$ & $31.5^{\mathrm{B}}$ & $33.5^{\mathrm{B}}$ \\
'Wigor' & $41.1^{\mathrm{C}}$ & $31.1^{\mathrm{D}}$ & $32.8^{\mathrm{BC}}$ \\
'Wołyńska' & $41.2^{\mathrm{C}}$ & $31.3^{\mathrm{CD}}$ & $29.1^{\mathrm{E}}$ \\
'Wróble' & $40.9^{\mathrm{D}}$ & $31.1^{\mathrm{DE}}$ & $33.5^{\mathrm{B}}$ \\
\hline Mean & $41.3^{3}$ & 31.3 & $31.6^{2}$ \\
\hline
\end{tabular}

Values marked with the same superscript letter do not differ significantly at $p<0.05$.

\subsection{Characteristics of Sour Cherry Kernel Oil}

Some of the chemical and physical properties of the oils obtained from P. cerasus kernels are shown in Table 2. The mean peroxide value was $1.49 \mathrm{mEq} \mathrm{O}_{2} / \mathrm{kg}$ oil, which was below the acceptable level for cold pressed or virgin oils according to the Codex Alimentarius Commission [15]. 'Koral' was found to have the lowest peroxide value amongst all the tested samples, i.e., $1.37 \mathrm{mEq} \mathrm{O} / 2 / \mathrm{kg}$ oil. The peroxide value of sour cherry kernel oil from Romania, was reported to be $1.6 \mathrm{mEq} \mathrm{O}_{2} / \mathrm{kg}$ oil [10], while from Iran- $0.99 \mathrm{mEq}$ $\mathrm{O}_{2} / \mathrm{kg}$ oil [6]. Many factors are responsible for the high peroxide value, including oxygen availability and temperature among others [16].

Table 2. Quality parameters of oils from kernel of eight sour cherry cultivars.

\begin{tabular}{|c|c|c|c|c|}
\hline Cultivar & $\begin{array}{c}\text { Acid Value } \\
(\mathrm{mg} \mathrm{KOH} / \mathrm{g})\end{array}$ & $\begin{array}{c}\text { Saponification Value } \\
(\mathrm{mg} \mathrm{KOH} / \mathrm{g})\end{array}$ & $\begin{array}{l}\text { Peroxide Value } \\
(\mathrm{mEq} \mathrm{O} / \mathrm{kg})\end{array}$ & $\begin{array}{c}\text { Iodine Value } \\
\left(\mathrm{g} \mathrm{I}_{2} / 100 \mathrm{~g}\right)\end{array}$ \\
\hline ‘Koral' & $1.00^{\mathrm{D}}$ & $182^{\mathrm{DE}}$ & $1.37^{\mathrm{D}}$ & $118^{\mathrm{D}}$ \\
\hline 'Lucyna' & $1.11^{\mathrm{C}}$ & $186^{\mathrm{BC}}$ & $1.45^{\mathrm{BCD}}$ & $118^{\mathrm{D}}$ \\
\hline 'Montmorency' & $1.36^{\mathrm{A}}$ & $191 \mathrm{~A}$ & $1.53 \mathrm{ABC}$ & $119^{C D}$ \\
\hline 'Naumburger' & $1.32^{\mathrm{A}}$ & $185^{\mathrm{BC}}$ & $1.63^{\mathrm{A}}$ & $123^{\mathrm{A}}$ \\
\hline 'Wanda' & $1.13^{C}$ & $181^{\mathrm{DE}}$ & $1.58^{\mathrm{AB}}$ & $120^{\mathrm{BC}}$ \\
\hline 'Wigor' & $1.21^{\mathrm{B}}$ & $183^{C D}$ & $1.48^{\mathrm{BCD}}$ & $121^{\mathrm{B}}$ \\
\hline ‘Wołyńska' & $1.20^{\mathrm{B}}$ & $187^{\mathrm{B}}$ & $1.43^{\mathrm{CD}}$ & $121^{\mathrm{B}}$ \\
\hline 'Wróble' & $1.12^{C}$ & $180^{\mathrm{E}}$ & $1.47^{\mathrm{BCD}}$ & $121^{\mathrm{B}}$ \\
\hline Mean & 1.20 & 184 & 1.49 & 120 \\
\hline
\end{tabular}

Values marked with the same superscript letter do not differ significantly at $p<0.05$.

The iodine value indicates the degree of unsaturation of fatty acids and exhibits stability of the oil against oxidation [6]. The iodine values of sour cherry oil of eight cultivars varied from 118 to $123 \mathrm{~g}$ of I2/100 $\mathrm{g}$ of oil, which is consistent with the findings reported by Lazos [11] (116 g of I2/100 g of oil) and Popa et al. [10] (122.5 g of I2/100 g of oil). Otherwise, the values determined were lower than those reported by Kazempour-Samak et al. [6] (130.99 $\mathrm{g}$ of I2/100 $\mathrm{g}$ of oil).

The results revealed that the mean saponification value of the oil sample was $184 \mathrm{mg}$ $\mathrm{KOH} / \mathrm{g}$ oil, which is in line with the findings reported by Popa et al. [10] (183 mg KOH/g oil). However, the highest saponification number of the 'Montmorency' (191 mg KOH/g oil) was lower than the values reported previously for sour cherry oil, i.e., $193 \mathrm{mg} \mathrm{KOH} / \mathrm{g}$ oil [17], $194 \mathrm{mg} \mathrm{KOH/g}$ oil [6], and $198 \mathrm{mg} \mathrm{KOH} / \mathrm{g}$ oil [11]. The free fatty acids in a sample were measured using the acid value assay. In the present study, the mean acid value of eight tested sour cherry oils was $1.20 \mathrm{mg} \mathrm{KOH} / \mathrm{g}$ oil, which was lower than the values reported in another study-1.36 mg KOH/g oil [6] and $1.45 \mathrm{mg} \mathrm{KOH} / \mathrm{g}$ oil [17]. Increased saponification and acid values indicate progressive oxidative processes, which adversely affect the quality of oils and is usually caused by storage changes and their duration. Thus, 
the comparison of these values with the literature data may be associated with the risk of error; nevertheless, it shows the rate of oxidation of the studied oils from various cultivars stored under identical conditions.

\subsection{Fatty Acid Composition of Sour Cherry Kernel Oil}

Table 3 shows the contents of fatty acids detected in oils obtained from kernels of various $P$. cerasus cultivars. Some inter-cultivar differences in the content of dominant fatty acids, including linoleic (39.1-46.2\%) and oleic (25.4-41.0\%) acid, as well as $\alpha$-eleostearic $(8.00-15.62 \%)$, palmitic (5.45-7.41\%), and stearic $(2.49-3.17 \%)$ acid were observed.

Table 3. Fatty acid composition in oils from different sour cherry cultivars.

\begin{tabular}{|c|c|c|c|c|c|c|c|c|c|}
\hline \multirow[b]{2}{*}{ Cultivar } & \multicolumn{9}{|c|}{ Fatty Acid Content (\%) } \\
\hline & C 16:0 & C 16:1 & C 18:0 & C 18:1 & C18:2 & $\alpha-\mathrm{C} 18: 3$ & $\begin{array}{c}\alpha-E S A \\
C 18: 3\end{array}$ & C 20:0 & C 20:1 \\
\hline 'Koral' & $5.95^{\mathrm{F}}$ & $0.23^{\mathrm{D}}$ & $3.17^{\mathrm{A}}$ & $38.4^{\mathrm{C}}$ & $42.2^{\mathrm{D}}$ & $0.20^{\mathrm{B}}$ & $8.18^{\mathrm{B}}$ & $1.12^{\mathrm{F}}$ & $0.47^{\mathrm{C}}$ \\
\hline 'Lucyna' & $6.43^{\mathrm{D}}$ & $0.33^{\mathrm{AB}}$ & $2.78^{\mathrm{D}}$ & $37.5^{\mathrm{D}}$ & $41.3^{\mathrm{F}}$ & $0.12 \mathrm{CD}$ & $8.13^{\mathrm{B}}$ & $1.19^{\mathrm{E}}$ & $0.60^{\mathrm{A}}$ \\
\hline 'Montmorency' & $6.10^{\mathrm{E}}$ & $0.29 \mathrm{BC}$ & $2.91^{\mathrm{C}}$ & $41.0^{\mathrm{A}}$ & $39.1^{\mathrm{G}}$ & $0.21^{\mathrm{B}}$ & $8.58^{\mathrm{B}}$ & $1.23^{\mathrm{D}}$ & $0.50^{\mathrm{C}}$ \\
\hline ‘Naumburger' & $7.41^{\mathrm{A}}$ & $0.32 \mathrm{AB}$ & $2.96^{\mathrm{B}}$ & $25.4^{\mathrm{F}}$ & $46.2^{\mathrm{A}}$ & $0.43^{\mathrm{A}}$ & $15.62^{\mathrm{A}}$ & $1.34^{\mathrm{A}}$ & $0.43^{\mathrm{D}}$ \\
\hline 'Wanda' & $5.45 \mathrm{H}$ & $0.35^{\mathrm{A}}$ & $2.70^{\mathrm{E}}$ & $39.2^{\mathrm{B}}$ & $42.0^{\mathrm{E}}$ & $0.11^{\mathrm{DE}}$ & $8.45^{\mathrm{B}}$ & $1.29 \mathrm{BC}$ & $0.56^{\mathrm{B}}$ \\
\hline 'Wigor' & $5.82^{G}$ & $0.30^{\mathrm{BC}}$ & $2.61^{\mathrm{F}}$ & $39.1^{\mathrm{B}}$ & $42.3^{\mathrm{C}}$ & $0.09^{\mathrm{E}}$ & $8.00^{\mathrm{B}}$ & $1.31^{\mathrm{AB}}$ & $0.49^{\mathrm{C}}$ \\
\hline 'Wołyńska' & $6.49^{C}$ & $0.26^{C D}$ & $2.81^{\mathrm{D}}$ & $35.2^{\mathrm{E}}$ & $44.6^{\mathrm{B}}$ & $0.21^{\mathrm{B}}$ & $8.69^{B}$ & $1.26^{C D}$ & $0.47^{\mathrm{C}}$ \\
\hline 'Wróble' & $7.32^{B}$ & $0.25^{\mathrm{D}}$ & $2.49^{G}$ & $37.5^{\mathrm{D}}$ & $42.4^{\mathrm{C}}$ & $0.14^{\mathrm{C}}$ & $8.50^{\mathrm{B}}$ & $1.19^{\mathrm{E}}$ & $0.34^{\mathrm{E}}$ \\
\hline Mean & 6.37 & 0.29 & 2.81 & 36.7 & 42.5 & 0.19 & 9.27 & 1.24 & 0.48 \\
\hline
\end{tabular}

C 16:0, palmitic acid; C 16:1, palmitoleic acid; C 18:0, stearic acid; C 18:1, oleic acid; C 18:2, linoleic acid; $\alpha$-C18:3, $\alpha$-linolenic acid; $\alpha$-ESA C 18:3- $\alpha$-eleostearic acid; C 20:0-arachidic acid; C 20:1-gondoic acid. Values marked with the same superscript letter do not differ significantly at $p<0.05$.

The above findings are consistent with the results reported by other authors $[5,8,10,11,13]$. Expectedly, the content of linoleic acid (42.5\%) was higher than that of oleic acid (36.7\%), which is consistent with some previously reported data [6,8]. An exception was 'Montmorency', whose content of oleic acid was higher $(41.0 \%)$, as compared to the content of linoleic acid (39.1\%), which is in agreement with the results of other authors, i.e., 42.9 and 38.2 [10], 45.8 and 41.8 [13], 46.0 and 41.6 [11], 63.9 and 27.0 [5], and $46.3 \%$ and $41.5 \%$ [12], respectively.

The above results demonstrate that the content of dominant fatty acids depends on the cherry cultivar from which the oil was obtained. Moreover, $\alpha$-eleostearic acid was found to be in third place, following oleic and linoleic acids and its content depended on the cultivar (8.00-15.62\%). The study findings are similar to the results reported by other authors, showing that the content of $\alpha$-eleostearic acid was 9.34 [6] or $7.43-15.76 \%$ [8]. In the present study, the content of palmitic acid ranged from 5.45 to $7.41 \%$ and the stearic acid value ranged from 2.49 to $3.17 \%$, which is similar to the results reported previously where the content of palmitic acid was 5.3 [5], 6.4 [12], 6.54 [6], 6.9 [13], 5.06-7.38 [8], 8.60 [11], and $11 \%$ [10] followed by the content of stearic acid, being 1.2 [12], 1.5 [5], 2.03 [6], 2.22-3.45 [8], 2.6 [13], 2.86 [11], and 6.4\% [10]. The minor content (below 2\%) of fatty acids in the oils evaluated in the present study was noted for arachidic acid, palmitoleic acid, $\alpha$-linolenic acid, and gondoic acid.

The differences in the content of individual fatty acids in oils from different sour cherry cultivars are associated with the differences in total saturated, total unsaturated, monounsaturated, and polyunsaturated fatty acids (Table 4). The content of total unsaturated fatty acids (UFA) (monounsaturated and polyunsaturated fatty acid) was higher than that of saturated fatty acids (SFA). All oil samples had high amounts of total unsaturated fatty acids, mainly linoleic acid and oleic acid. Moreover, the polyunsaturated fatty acid level (47.9-62.2\%) was higher than that of monounsaturated fatty acids (26.2-41.8\%) in all the samples studied. Similar results reported by Górnaś et al. have demonstrated higher 
percentages of PUFA (44.0-62.3\%) compared to MUFA (26.0-46.1\%) in oils obtained from kernels of various sour cherry cultivars [6]. The results of the present study are consistent with the findings reported by Kazempour-Samak et al., according to which the content of PUFA and MUFA was $52.66 \%$ and $36.14 \%$, respectively [6]. Different results were reported by Uluata and Özdemir; in their study the content of PUFA (42.4\%) was found to be lower than that of MUFA (49.1\%) [13]. The ratios of $\Sigma$ UFA/ $\Sigma$ SFA and $\Sigma$ PUFA/ $(\Sigma$ SFA $+\Sigma$ MUFA) in the oil from kernels of different $P$. cerasus cultivars were within the range of 8.11-9.59 and 0.92-1.65, respectively, which is comparable to the findings reported by Górnaś et al., i.e., 7.5-9.6 and 0.8-1.7, respectively [8].

Table 4. Sum of SFA, MUFA, and PUFA (\%), and fatty acid ratios of sour cherry kernel oils.

\begin{tabular}{|c|c|c|c|c|c|c|}
\hline Cultivar & $\Sigma$ SFA & $\Sigma$ MUFA & $\Sigma$ PUFA & $\begin{array}{l}\text { Fatty Acids Ratio } \\
\Sigma \text { UFA } / \Sigma \text { SFA }\end{array}$ & $\begin{array}{l}\text { Fatty Acids Ratio } \Sigma \text { PUFA/ } \\
(\Sigma \text { SFA }+\Sigma \text { MUFA })\end{array}$ & $\begin{array}{c}\text { PUFA Ratio } \\
\text { n-6/n-3 }\end{array}$ \\
\hline ‘Koral' & $10.3^{C}$ & $39.1^{C}$ & $50.6^{\mathrm{CD}}$ & $8.75^{\mathrm{C}}$ & $1.02^{C}$ & $5.03^{\mathrm{A}}$ \\
\hline 'Lucyna' & $11.4^{\mathrm{C}}$ & $38.8^{\mathrm{C}}$ & $49.5^{\mathrm{E}}$ & $8.46^{\mathrm{D}}$ & $1.01^{\mathrm{C}}$ & $5.00^{\mathrm{A}}$ \\
\hline 'Montmorency' & $10.2^{C}$ & $41.8^{\mathrm{A}}$ & $47.9^{\mathrm{F}}$ & $8.76^{\mathrm{C}}$ & $0.92^{\mathrm{D}}$ & $4.46^{\mathrm{B}}$ \\
\hline 'Naumburger' & $11.7^{\mathrm{A}}$ & $26.1^{\mathrm{F}}$ & $62.2^{\mathrm{A}}$ & $7.54^{\mathrm{F}}$ & $1.65^{\mathrm{A}}$ & $2.87^{\mathrm{C}}$ \\
\hline 'Wanda' & $9.4^{\mathrm{D}}$ & $40.1^{\mathrm{B}}$ & $50.5^{\mathrm{D}}$ & $9.59 \mathrm{~A}$ & $1.02^{C}$ & $4.91 \mathrm{AB}$ \\
\hline 'Wigor' & $9.7^{\mathrm{D}}$ & $39.9^{\mathrm{B}}$ & $50.4^{\mathrm{D}}$ & $9.27^{\mathrm{B}}$ & $1.02^{C}$ & $5.22^{\mathrm{A}}$ \\
\hline ‘Wołyńska' & $10.6^{\mathrm{C}}$ & $36.0^{\mathrm{E}}$ & $53.5^{\mathrm{B}}$ & $8.47^{\mathrm{D}}$ & $1.15^{\mathrm{B}}$ & $5.01^{\mathrm{A}}$ \\
\hline 'Wróble' & $11.0^{\mathrm{B}}$ & $38.0^{\mathrm{D}}$ & $51.0^{C}$ & $8.11^{\mathrm{E}}$ & $1.04^{C}$ & $4.91 \mathrm{AB}$ \\
\hline Mean & 10.5 & 37.4 & 52.0 & 8.62 & 1.10 & 4.68 \\
\hline
\end{tabular}

The composition of fatty acids is of particular importance for the nutritional value of oil. SFA and MUFA can be synthesised in the human body while PUFA cannot be due to the lack of enzymatic systems capable of introducing double bonds in the n- 6 and n-3 positions of the carbon chain and have to be supplied daily with food. The ratio of acids from the n-6 to n-3 family (4-5:1, without exceeding the value of $10: 1$ for adults) in the diet is important, because an excess of n- 6 fatty acids inhibits the metabolism of n-3 fatty acids, which may lead to a physiological imbalance of hormone-like substances synthesised from them called eicosanoids and docosanoids (including prostaglandins (PGs), thromboxanes (TXs), prostacyclin (PGI2), leukotrienes (LTs), resolvins (RVD), and other lipid mediators) [18]. The results obtained in the present paper show that sour cherry kernel oil is characterized by a favourable quantitative ratio of n-6/n-3 fatty acids.

The vegetable oils obtained from seeds or fruits of plants traditionally considered to be oily raw materials (rapeseed, sunflower, olive, and soybean oil), but also oils from atypical vegetable raw materials (pumpkin oil, grape, hemp, evening primrose, and others) can be used both as ingredients of nutritional (food) supplements, nutricosmetics and cosmetics (Figure 1). SFA determine the stability of the oil, while PUFA are responsible for health benefits $[19,20]$. The sum of SFA (mean 10.5), MUFA (mean 37.4), and PUFA (mean 52.0\%) in the tested cherry oils was found to be similar to the commonly consumed oils, such as sunflower, corn, pumpkin seed, or wheat germ oils. 


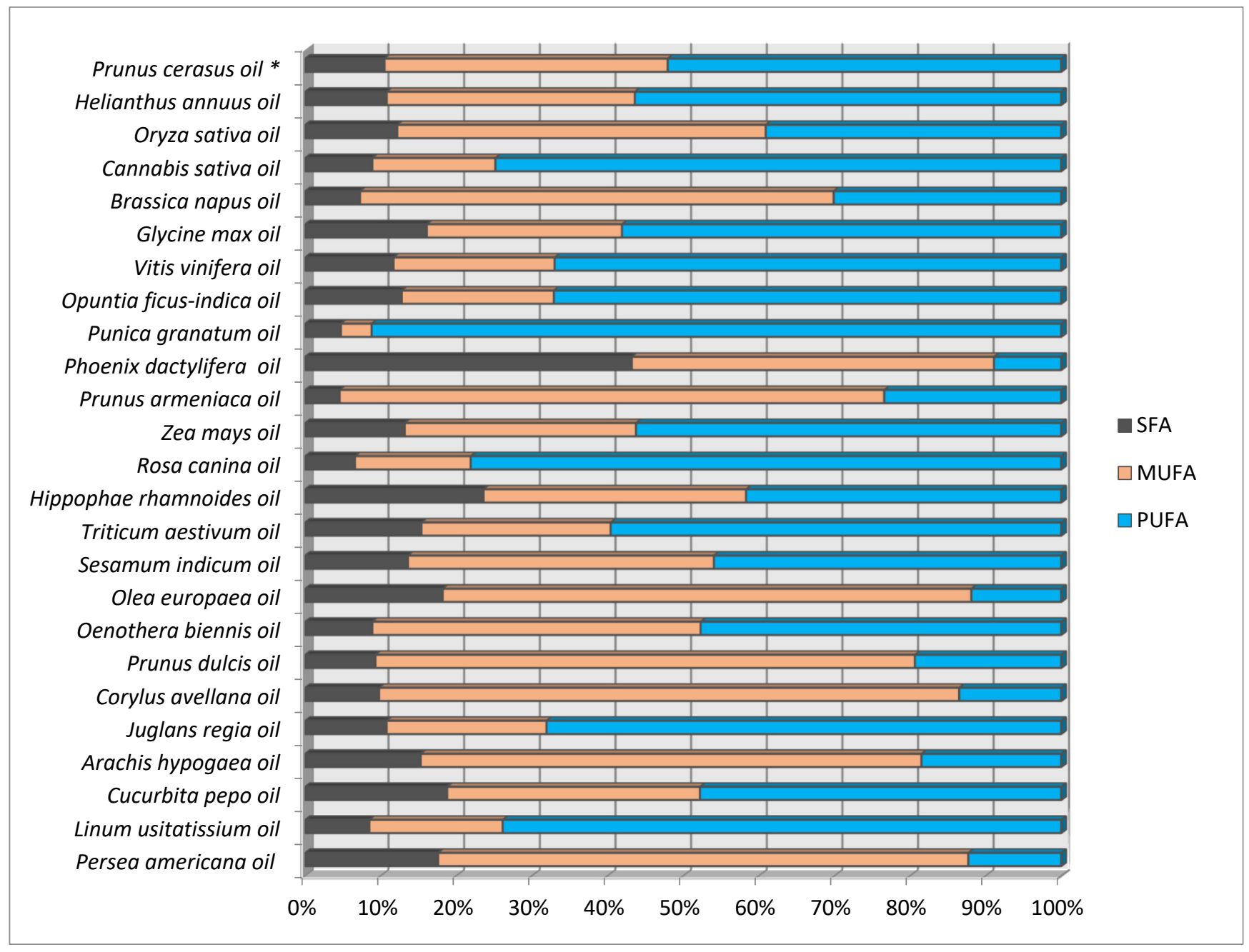

Figure 1. Saturated fatty acids (SFA), monounsaturated fatty acids (MUFA), and polyunsaturated fatty acids (PUFA) in sour cherry oils (mean for eight cultivars) in comparison with selected conventional plant oils. Source: * data obtained from our own research; all other data from literature [21-26].

Sour cherry kernel oil, with low content of saturated fatty acids and the high content of unsaturated fatty acids, is highly favourable in human nutrition and health. It is known that unsaturated fatty acids are of importance to the human body and skin health [19]. Monounsaturated oleic acid with a number of potential health effects (including improvement of immune system function, maintenance of normal blood cholesterol levels, and impact on the modulation of inflammatory markers) is a possible ingredient of functional foods [27]. Polyunsaturated linoleic acid, an omega- 6 essential fatty acid, shows beneficial effects on lipid profile, glucose metabolism, and cardiovascular disease risk reduction [28]. Oleic and linoleic acids are the only unsaturated fatty acids detected in the stratum corneum [29]. Linoleic acid, a component of ceramide 1, plays an important role in the cohesiveness of the intracellular cement and proper functioning of the skin barrier limiting the transepidermal water loss (TEWL), thus ensuring adequate hydration and protecting against external factors [19].

\subsection{Sterol Composition and Squalene Content of Sour Cherry Kernel Oil}

Phytosterols, steroid compounds present in plants, cannot be synthesized by humans. They exhibit the ability to reduce LDL-cholesterol concentrations in humans, which reduces the risk of cardiovascular diseases. Moreover, sterols are believed to have anti-inflammatory, antibacterial, antiulcer, antioxidant, and anticancer activities [30]. Squalene, a natural 
triterpene widely distributed in plant oils, which can easily move through the cellular and subcellular membrane, exerts antibacterial, antifungal, and antioxidant effects [31]. Squalene, as the main component of skin surface polyunsaturated lipids, protects the skin cells against free radical oxidative damage and has moisturizing as well as emollient properties [32].

Besides other components of the unsaponifiable fraction, such as phospholipids, tocopherols, tocotrienols, and carotenoids, sterols and squalene give the oils a high nutritional value. Their percentages in oils depend on the type of raw material, its cultivars and climate conditions [33].

The total amount of sterols in the oils of eight cultivars ranged from 336 to $973 \mathrm{mg} / 100 \mathrm{~g}$ oil (Table 5). $\beta$-sitosterol was found in the largest amount. The content of this compound varied significantly depending on the cultivar. These results are consistent with those reported by Lazos [11], Górnaś et al. [8], Korlesky et al. [17], and Kazempour-Samak et al. [6]. Other major sterol compounds were $\Delta 5$-avenasterol, 24-methylene-cycloartanol, cholesterol, and campesterol, in lower amounts-gramisterol, $\Delta 7$-stigmasterol, and citrostadienol. The content of squalene in sour cherry kernel oil was considerable. The highest amount of squalene was observed in 'Montmorency' (102 mg/100 g oil) while the lowest one in 'Koral' (66 mg/100 g oil). The above amounts are comparable to the amounts of squalene in other cultivars of sour cherries grown in Poland, which ranged between 65.8 and $102.8 \mathrm{mg} / 100 \mathrm{~g}$ oil [8].

Table 5. Sterol and squalene content (mg/100 g oil) in sour cherry kernel oils.

\begin{tabular}{|c|c|c|c|c|c|c|c|c|c|c|c|}
\hline \multirow[b]{2}{*}{ Cultivar } & \multicolumn{10}{|c|}{ Sterols } & \multirow[b]{2}{*}{ Squalene } \\
\hline & 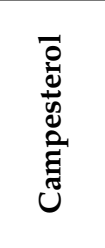 & $\begin{array}{l}0 \\
0 \\
0 \\
0 \\
0 \\
0 \\
\dot{0} \\
1 \\
0 \\
0\end{array}$ & 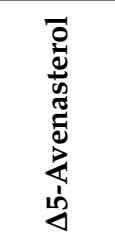 & 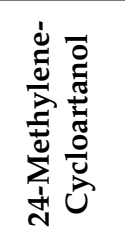 & 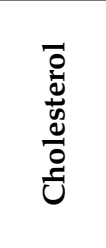 & 吕 & 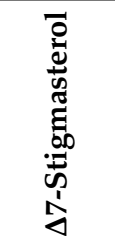 & 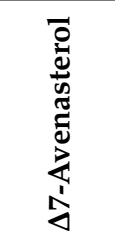 & 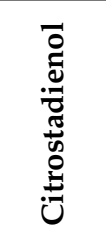 & $\underset{\tilde{J}}{\tilde{\theta}}$ & \\
\hline 'Koral' & $9.7^{\mathrm{C}}$ & $260^{\mathrm{F}}$ & $20.5^{C}$ & $24.7^{\mathrm{B}}$ & $9.3^{C}$ & $3.6^{\mathrm{D}}$ & $\begin{array}{c}2.17 \\
\text { CD }\end{array}$ & $3.07^{C}$ & $3.13^{\mathrm{B}}$ & $336^{\mathrm{F}}$ & $66^{\mathrm{F}}$ \\
\hline 'Lucyna' & $7.7^{\mathrm{DE}}$ & $284^{\mathrm{E}}$ & $15.7 \mathrm{EF}$ & $22.6^{C}$ & $12.3^{\mathrm{B}}$ & $3.3^{\mathrm{E}}$ & N.D. & $2.33^{\mathrm{D}}$ & N.D. & $348^{\mathrm{E}}$ & $69^{\mathrm{E}}$ \\
\hline 'Montmorency' & $22.7^{\mathrm{B}}$ & $732^{\mathrm{B}}$ & $74.2^{\mathrm{B}}$ & $29.1^{\mathrm{A}}$ & $2.7^{\mathrm{D}}$ & $11.4^{\mathrm{B}}$ & $10.2^{\mathrm{B}}$ & $5.57^{\mathrm{B}}$ & $5.03^{\mathrm{A}}$ & $893^{B}$ & $102^{\mathrm{A}}$ \\
\hline 'Naumburger' & $39.4^{\mathrm{A}}$ & $790^{\mathrm{A}}$ & $76.7^{\mathrm{A}}$ & $29.7^{A}$ & $2.6^{\mathrm{D}}$ & $12.4^{\mathrm{A}}$ & $10.8^{\mathrm{A}}$ & $6.03^{\mathrm{A}}$ & $5.40^{\mathrm{A}}$ & $973^{\mathrm{A}}$ & $78^{C}$ \\
\hline 'Wanda' & $8.2^{\mathrm{D}}$ & $318^{C}$ & $15.4^{\mathrm{EF}}$ & $21.9^{C D}$ & $14.3^{\mathrm{A}}$ & $6.1^{C}$ & $2.33^{C}$ & $1.77^{\mathrm{E}}$ & $2.27^{\mathrm{C}}$ & $390^{C}$ & $75^{\mathrm{D}}$ \\
\hline 'Wigor' & $7.2^{\mathrm{EF}}$ & $253^{\mathrm{G}}$ & $16.2^{\mathrm{D}}$ & $20.8^{\mathrm{DE}}$ & $12.7^{\mathrm{B}}$ & $2.7^{\mathrm{F}}$ & $1.77^{\mathrm{D}}$ & $1.47^{\mathrm{EF}}$ & $2.57^{\mathrm{C}}$ & $318^{\mathrm{G}}$ & $82^{B}$ \\
\hline 'Wołyńska' & $8.0^{\mathrm{D}}$ & $285^{\mathrm{E}}$ & $15.7^{\mathrm{EF}}$ & $21.6^{\mathrm{CD}}$ & $12.2^{\mathrm{B}}$ & $3.3^{\mathrm{E}}$ & $1.63^{\mathrm{DE}}$ & $1.30^{\mathrm{F}}$ & N.D. & $348^{\mathrm{E}}$ & $82^{B}$ \\
\hline 'Wróble' & $7.1^{\mathrm{F}}$ & $291^{D}$ & $15.0^{\mathrm{F}}$ & $20.3^{\mathrm{E}}$ & $12.8^{\mathrm{B}}$ & $2.9^{\mathrm{F}}$ & $1.17^{\mathrm{E}}$ & $1.53^{\mathrm{EF}}$ & $2.53^{C}$ & $354^{\mathrm{D}}$ & $80^{\mathrm{BC}}$ \\
\hline Mean & 13.8 & 401 & 31.2 & 23.9 & 9.9 & 5.69 & 4.30 & 2.88 & 3.49 & 495 & 79.3 \\
\hline
\end{tabular}

N.D. not detected. Values marked with the same superscript letter do not differ significantly at $p<0.05$.

\subsection{Phytochemical Content and Antioxidant Potential of Sour Cherry Kernel Oil}

Tocochromanols are the important lipophilic compounds with antioxidant activity in sour cherry oil. The total concentration of tocochromanols ranges between 119 and $164 \mathrm{mg} / 100 \mathrm{~g}$ (Table 6). The vitamin capacity of tocopherols is related to the content of $\alpha$-tocopherol (vitamin E), as the most biologically active. Vitamin E inhibits the production of new free radicals, protect against lipid peroxidation, is involved in various physiological and biochemical functions of the body, reduces the risk of cardiovascular diseases, cancer, or age-related macular degeneration, and plays an important role in maintaining skin health $[19,34]$. The range and average of $\alpha$-T in kernel oils recovered from various sour cherry cultivars were 9.2-35.7 and $18.0 \mathrm{mg} / 100 \mathrm{~g}$. According to Uluata and Özdemir [13], 
the content of $\alpha$-T was $74.7 \mathrm{mg} / \mathrm{kg}$; according to Matthäus and Özcan [5]—4.7 mg/kg. Some study results show that $\gamma$-tocopherol is a better negative risk factor for certain types of cancer and myocardial infarction than $\alpha$-tocopherol [35]. The results obtained in this study demonstrate that the amounts of $\gamma$-T in the study oils were much higher, as compared to $\alpha$-T. The differences in $\gamma$-T content in the sour cherry oils were substantial depending on the cultivar and ranged from $85.8 \mathrm{mg} / 100 \mathrm{~g}$ ('Naumburger') to $132.5 \mathrm{mg} / 100 \mathrm{~g}$ ('Lucyna'). $\gamma$-T was also the main tocochromanol present in other cultivars of sour cherries grown in Poland; its levels ranged between 89.1 and $133.3 \mathrm{mg} / 100 \mathrm{~g}$ oil [8]. According to other authors [5,13], the content of $\gamma$-T was lower, i.e., $579.9 \mathrm{mg} / \mathrm{kg}$ oil [13], and $197.2 \mathrm{mg} / \mathrm{kg}$ oil [5].

Table 6. Phytochemical compounds with antioxidant effects in sour cherry kernel oils.

\begin{tabular}{|c|c|c|c|c|c|c|c|c|c|c|c|}
\hline \multirow{2}{*}{ Cultivar } & \multicolumn{7}{|c|}{ Tocochromanols (mg/100 g Oil) } & \multirow{2}{*}{$\begin{array}{c}\mathrm{TC} \\
(\mathrm{mg} / 100 \mathrm{~g})\end{array}$} & \multirow{2}{*}{$\begin{array}{c}\text { TP } \\
(\mu \mathrm{g} \mathrm{GAE} / \mathrm{g})\end{array}$} & \multirow{2}{*}{$\begin{array}{c}\begin{array}{c}\text { DPPH } \\
(\mathrm{mg}\end{array} \\
\text { Trolox/100 g) }\end{array}$} & \multirow{2}{*}{$\begin{array}{c}\begin{array}{c}\text { ABTS } \\
(\mathrm{mg}\end{array} \\
\text { Trolox/100 g) }\end{array}$} \\
\hline & $\alpha-\mathrm{T}$ & $\beta-\mathrm{T}$ & $\gamma-\mathrm{T}$ & $\delta-T$ & $\alpha-\mathrm{T3}$ & $\gamma-\mathrm{T} 3$ & Total & & & & \\
\hline 'Koral' & $9.2^{\mathrm{G}}$ & $0.40^{\mathrm{F}}$ & $123.7^{\mathrm{B}}$ & $10.5^{\mathrm{G}}$ & $0.87^{\mathrm{D}}$ & $0.3^{\mathrm{B}}$ & $145^{\mathrm{B}}$ & $0.56^{\mathrm{D}}$ & $19.6^{\mathrm{G}}$ & $57.9^{\mathrm{EF}}$ & $38.2^{\mathrm{G}}$ \\
\hline 'Lucyna' & $10.2^{\mathrm{F}}$ & $0.50^{\mathrm{E}}$ & $132.5^{\mathrm{A}}$ & $18.6^{\mathrm{A}}$ & $1.67^{\mathrm{B}}$ & $0.4^{\mathrm{A}}$ & $164^{\mathrm{A}}$ & $0.59^{\mathrm{D}}$ & $19.6^{\mathrm{G}}$ & $58.2^{\mathrm{E}}$ & $39.4^{\mathrm{E}}$ \\
\hline 'Montmorency' & $29.1^{\text {B }}$ & $1.17^{\mathrm{B}}$ & $88.6^{\mathrm{F}}$ & $12.4^{\mathrm{D}}$ & $0.60^{\mathrm{E}}$ & $0.3^{\mathrm{B}}$ & $132^{\mathrm{D}}$ & $1.06^{\mathrm{B}}$ & $28.5^{\mathrm{B}}$ & $62.7^{\mathrm{B}}$ & $40.4^{\mathrm{D}}$ \\
\hline 'Naumburger' & $35.7^{\mathrm{A}}$ & $2.33^{\mathrm{A}}$ & $85.8^{\mathrm{G}}$ & $11.7^{\mathrm{E}}$ & $2.17^{\mathrm{A}}$ & $0.2^{\mathrm{C}}$ & $138^{\mathrm{C}}$ & $1.61^{\mathrm{A}}$ & $29.5^{\mathrm{A}}$ & $61.2^{\mathrm{C}}$ & $43.2^{\mathrm{A}}$ \\
\hline 'Wanda' & $14.6^{\mathrm{D}}$ & $0.58^{\mathrm{DE}}$ & $98.2^{\mathrm{C}}$ & $9.7^{\mathrm{H}}$ & $0.75^{\mathrm{D}}$ & $0.3^{\mathrm{B}}$ & $124^{\mathrm{F}}$ & $0.77^{\mathrm{C}}$ & $22.7^{\mathrm{C}}$ & $63.1^{\mathrm{AB}}$ & $39.1^{\mathrm{EF}}$ \\
\hline 'Wigor' & $18.5^{\mathrm{C}}$ & $0.68^{\mathrm{C}}$ & $91.2^{\mathrm{E}}$ & $14.2^{\mathrm{C}}$ & $1.13^{\mathrm{C}}$ & $0.2^{\mathrm{C}}$ & $126^{\mathrm{E}}$ & $0.73^{C}$ & $21.6^{\mathrm{D}}$ & $63.5^{\mathrm{A}}$ & $38.7^{\mathrm{FG}}$ \\
\hline 'Wołyńska' & $12.7^{\mathrm{E}}$ & $0.60^{\mathrm{CD}}$ & $88.6^{\mathrm{F}}$ & $15.7^{\mathrm{B}}$ & $0.87^{\mathrm{D}}$ & $0.2^{\mathrm{C}}$ & $119^{\mathrm{G}}$ & $0.63^{\mathrm{D}}$ & $20.2^{\mathrm{F}}$ & $57.7^{\mathrm{F}}$ & $42.5^{\mathrm{B}}$ \\
\hline 'Wróble' & $14.1^{\mathrm{D}}$ & $0.60^{\mathrm{CD}}$ & $96.8^{\mathrm{D}}$ & $11.3^{\mathrm{F}}$ & $0.53^{\mathrm{E}}$ & $0.2^{\mathrm{C}}$ & $124^{\mathrm{F}}$ & $0.81^{\mathrm{C}}$ & $20.7^{\mathrm{E}}$ & $58.7^{\mathrm{D}}$ & $41.8^{\mathrm{C}}$ \\
\hline Mean & 18.0 & 0.86 & 100.7 & 13.0 & 1.07 & 0.3 & 134 & 0.84 & 22.8 & 60.4 & 40.4 \\
\hline
\end{tabular}

$\mathrm{ABTS}^{\bullet+}, 2,2^{\prime}$-azinobis-(3-ethylbenzothiazoline-6-sulfonic acid); DPPH ${ }^{\bullet}$, 2,2' $^{\prime}$-diphenyl- 1-picrylhydrazyl; GAE gallic acid equivalent; $\alpha$-T, $\alpha$-tocopherol; $\beta$-T, $\beta$-tocopherol; $\gamma$-T, $\gamma$-tocopherol; $\delta$-T, $\delta$-tocopherol; $\alpha$-T3, $\alpha$ tocotrienol; $\gamma$-T3, $\gamma$-tocotrienol; TC, total carotenoids; TP, total polyphenols. Values marked with the same superscript letter do not differ significantly at $p<0.05$.

Polyphenols constitute an important group of compounds in sour cherry oil, which are characterised by multidirectional biological activity. They exhibit anti-inflammatory, antibacterial, antifungal, antiviral, antiallergic, as well as anticancer properties. Besides carotenoids, polyphenols act as antioxidants protecting the human cells, tissues, and the entire body against the destructive effects of free radicals. They play an extremely important role in skin protection against environmental factors [19]. The average value of polyphenols in the sour cherry kernel oils was $22.8 \mu \mathrm{g} / \mathrm{g}$ oil (expressed as GAE) (Table 6). A comparable content of total polyphenols (18.5 $\mu \mathrm{g}$ GAE/g oil) in sour cherry kernel oils was reported previously [13]. The findings of the present study concerning the content of carotenoids (0.84 mg/100 g oil, on average) are consistent with the findings of other authors [8,12].

The free radical scavenging capacity of the studied oils, determined using the common antioxidant methods of $\mathrm{DPPH}^{\bullet}$ and $\mathrm{ABTS}^{\bullet}{ }^{\bullet}$, ranged from $57.7-63.5$ to $38.2-43.2 \mathrm{mg}$ trolox/100 g oil, respectively. The results concerning the oil from cultivars of sour cherries grown in Poland were comparable with the value in the oil samples harvested in Turkey (57.4 and $38.7 \mathrm{mg}$ trolox/100 g oil, respectively) reported by Uluata and Özdemir [13].

Since it is difficult to compare the oils studied as to their antioxidant properties based on Table 6, the data were subjected to cluster analysis (Figure 2). Based on the dendrogram, the group of cultivars characterised by high similarity can be distinguished, i.e., 'Wanda', 'Wróble', 'Wigor', and 'Wołyńska' as well as 'Montmorency' and 'Naumburger'. 'Koral' and 'Lucyna' were distinctly different from other cultivars. Moreover, the similarity between them was relatively low. 


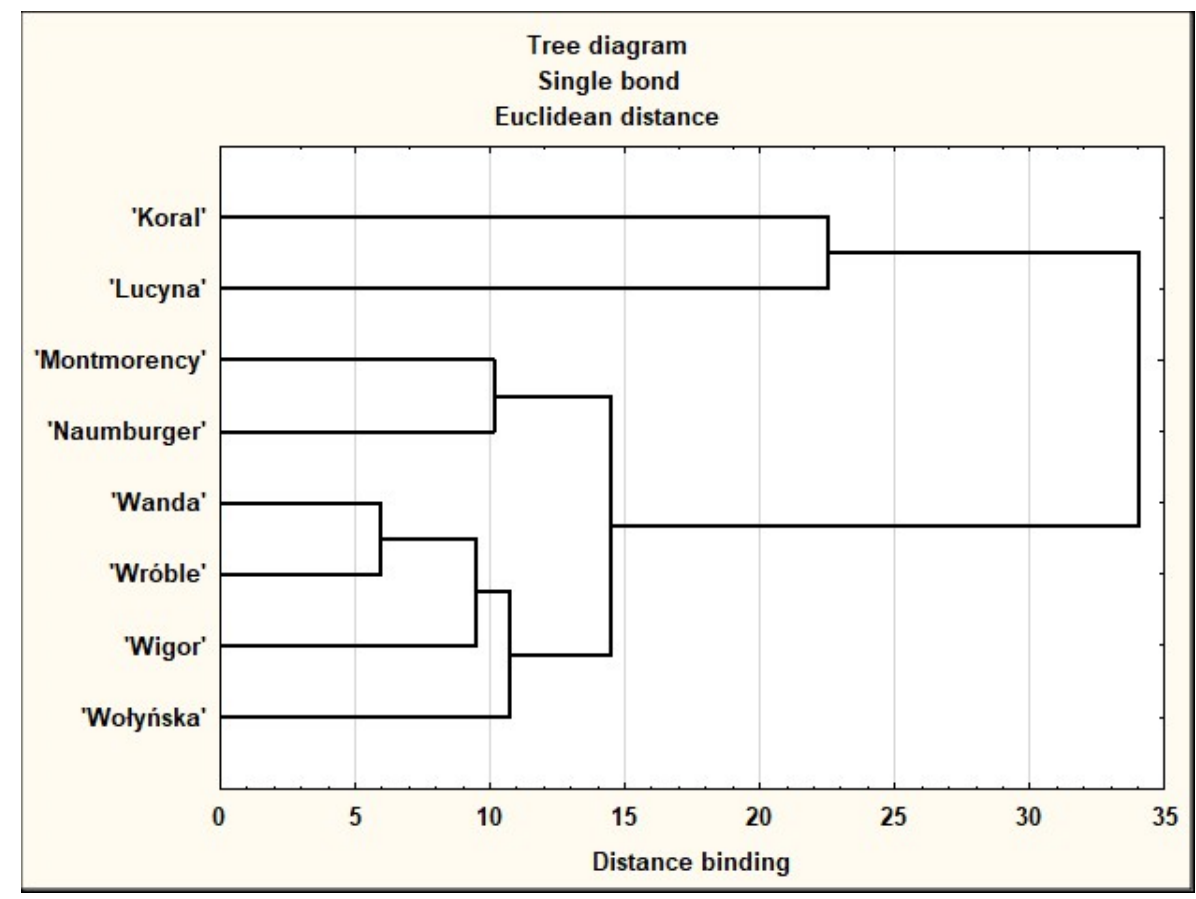

Figure 2. Dendrogram of eight sour cherry cultivars based on numerical data for bioactive compounds with antioxidative properties in the studied oils, including derivatives of tocopherols $(\alpha, \beta, \gamma, \delta)$ and tocotrienols $(\alpha, \gamma)$, total tocochromanol, total carotenoid, and total polyphenol content, as well as the $\mathrm{DPPH}^{\bullet}$ and $\mathrm{ABTS}^{\bullet+}$ radical scavenging capacities.

\section{Materials and Methods}

\subsection{Plant Material}

The plant material consisted of the kernels of eight cultivars of sour cherry (P. cerasus L.): 'Koral', 'Lucyna', 'Montmorency', 'Naumburger', 'Wanda', 'Wigor', 'Wołyńska', and 'Wróble'. Sour cherry fruits were harvested in August 2017 and 2018 from 6- and 7-year-old trees grown in an organic orchard in south-eastern Poland, near Chełm $\left(51^{\circ} 7^{\prime} \mathrm{N}, 23^{\circ} 28^{\prime} \mathrm{E}\right)$. All results are reported as the mean of the two years of study, due to insignificant differences for the research seasons.

\subsection{Sample Preparation}

Immediately after harvesting, the kernels were hand-separated from the fruit, washed with tap water, and oven dried at $40{ }^{\circ} \mathrm{C}$ (Memmert GmbH \& Co. KG, Germany, Schwabach ) for $24 \mathrm{~h}$. After removal of the seed coating, seed kernel samples (50 $\mathrm{g}$ of each cultivar) were crushed in a commercial blender (MICROTRON ${ }^{\circledR}$ MB 550, Kinematica AG, Malters, Switzerland). The crushed material, packed in a paper thimble, was placed in a Soxhlet extractor connected to a condenser and a $500 \mathrm{~mL}$ round-bottom flask. The extraction was performed with diethyl ether $(250 \mathrm{~mL})$ in a water bath for $6 \mathrm{~h}$. Then the solvent was removed under reduced pressure using a rotary evaporator (Rotavapor ${ }^{\circledR} \mathrm{R}-100$, Buchi Labortechnik AG, Flawil, Switzerland).

\subsection{Analysis of the Main Components of Kernels}

The content of crude fat was determined using the AOAC Official Method [36]. Crude fat was dried in $\mathrm{Na}_{2} \mathrm{SO}_{2}$ (anhydrous sodium sulphate); subsequently, the remaining solvent was evaporated in an evaporator and the pure oil obtained was determined qualitatively.

The protein content was determined in the defatted kernels by the Kjeldahl method according to the International Organization for Standardization (ISO) [37]. 


\subsection{Analysis of the Chemical Properties and Oxidative Stability of Oils}

The selected chemical properties of the oils were determined, i.e., saponification, peroxide, acid, and iodine values. The measurements were performed with an AT 1000 automatic titrator. The following were determined: the saponification value according to ISO 3657:2013 [38] and titrated with $0.5 \mathrm{~mol} / \mathrm{L} \mathrm{HCl}$. The peroxide value was determined according to the ISO 3960:2007 [39] standard method. The samples were titrated with a $0.002 \mathrm{~N}$ solution of sodium thiosulfate. The free fatty acid (FFA) content determined using the ISO 660:2009 [40] standard protocol. A $1 \mathrm{~g}$ sample of oil was dissolved in $20 \mathrm{~mL}$ of a mixed dichloromethane/ethanol $(1 / 1, v / v)$ solution and titrated with $0.1 \mathrm{M}$ potassium hydroxide solution. The acid value by multiplying the FFA value by a factor of 1.99 . The iodine value determined using the iodine monochloride (Wijs solution), as described in the ISO 3961:2009 [41] method. The samples were titrated with $0.1 \mathrm{~N}$ sodium thiosulfate.

\subsection{Analysis of Fatty Acid Composition}

Fatty acid profiles were measured by gas chromatography according to ISO standards $[42,43]$. The oil samples $(100 \mathrm{~mL}$ each) were converted to their fatty acid methyl esters (FAMEs). The FAME samples were analysed in a gas chromatograph (Shimadzu GC-2010 PLUS) equipped with a flame ionisation detector. A highly polar BPX 70 capillary column $(60 \mathrm{~m} \times 0.25 \mathrm{~mm}, 25 \mu \mathrm{m})$ was used for separation. The column was programmed in a temperature range between 140 and $210^{\circ} \mathrm{C}$, the dosing temperature was $210^{\circ} \mathrm{C}$, and the detector temperature was set at $250{ }^{\circ} \mathrm{C}$. The carrier gas was 6.0 helium, with a constant flow rate of $2 \mathrm{~mL} / \mathrm{min}$.

\subsection{Determination of Tocochromanols, Total Carotenoids, and Polyphenols}

Tocopherol and tocotrienol homologues were determined by HPLC (HP 1100 with a UV detector) according to PN-EN 12822:2014-08 [44]. The analysis was carried out in the reversed-phase mode. The oil sample was dissolved in methanol and applied to the top of a Supelcosil LC- 18 column $(25 \mathrm{~cm} \times 4.6 \mathrm{~mm}, 5 \mu \mathrm{m})$. The separation was carried out at $30^{\circ} \mathrm{C}$. The mobile phase was methanol/water $(97: 3, v / v)$ and the flow rate was $1 \mathrm{~mL} / \mathrm{min}$. Individual $\alpha, \gamma$, and $\delta$ isomers were determined at $292 \mathrm{~nm}$. Total tocochromanols were calculated by summing up the contents of all tocopherols and tocotrienols.

Total carotenoids were determined spectrophotometrically; $0.2 \mathrm{~g}$ of oil sample was diluted with n-hexane in $5 \mathrm{~mL}$ volumetric flasks and the absorbance was measured at $450 \mathrm{~nm}$ with a UV-2600i spectrophotometer (Shimadzu, Kyoto, Japan).

The total carotenoid concentration in oil samples was spectrophotometrically quantitated using the molar extinction coefficient for all-trans- $\beta$-carotene $(\varepsilon=139,049)$ and converted equations of the Beer-Lambert law and molar concentration.

$$
\begin{gathered}
\mathrm{c}=(\mathrm{A} / \varepsilon) \times 1 \\
\mathrm{~m}=\mathrm{c} \times \mathrm{MW} \times \mathrm{V}
\end{gathered}
$$

where $\mathrm{c}$-concentration $(\mathrm{mol} / \mathrm{L})$; A-absorbance; $\varepsilon$-molar extinction coefficient $(\mathrm{L} / \mathrm{mol} \times \mathrm{cm})$; l-path-length (cm); m-mass of total carotenoids in the sample (g); MW-molecular weight $(\mathrm{g} / \mathrm{mol})$; and $\mathrm{V}$-volume of solution $(\mathrm{L})$.

Determination of the total polyphenol content (TPC) was based on the Folin-Ciocalteu total phenolic assay [45], using gallic acid as a reference standard. Absorbance of the samples was measured with a UV-Vis spectrophotometer (UV-2600, Shimadzu, Kyoto, Japan) at $725 \mathrm{~nm}$. The results were expressed as gallic acid equivalent ( $\mu \mathrm{g}$ GAE/g oil).

\subsection{Total Antioxidant Capacity}

The extracts containing the polar fraction of oils were prepared according to SzydłowskaCzerniak et al. [46]. A $10 \mathrm{~mL}$ volume of methanol and water $(70: 30 \mathrm{v} / \mathrm{v})$ was added to $2 \mathrm{~g}$ of oil and extraction was carried out for $1 \mathrm{~h}$ without access to light. The samples were then frozen at $-20^{\circ} \mathrm{C}$ for another hour until the layers were separated. The extract 
was separated from the oil by quantitative transfer to glass flasks and stored in a freezer $\left(-20^{\circ} \mathrm{C}\right)$ until analysis.

The antioxidant capacity values of methanolic extracts were determined using $\mathrm{DPPH}^{\bullet}$ (1,1-diphenyl-2-picrylhydrazyl) assay according to the method described by Singh et al. [47]; $0.1 \mathrm{~mL}$ extract and $2 \mathrm{~mL}$ methanolic DPPH solution were mixed. The mixture was vigorously shaken and incubated at room temperature for $30 \mathrm{~min}$. The absorbance was recorded at $517 \mathrm{~nm}$ by a spectrophotometer (UV-2600i, Schimadzu, Kyoto, Japan).

The $^{\mathrm{ABTS}^{\bullet+}}$ antioxidant activity was determined according to Re et al. [48]. Firstly, the ABTS radical was prepared as $7 \mathrm{mM}$ ABTS water solutions and $2.45 \mathrm{mM}$ potassium persulfate (1:0.5 ratio, $v: v)$, which were mixed and diluted with ethanol until the absorbance (at $734 \mathrm{~nm}$ ) was 0.70 . Subsequently, $1 \mathrm{~mL}$ of ABTS radical was added into $20 \mu \mathrm{L}$ of sample. The absorbance was read at $734 \mathrm{~nm}$. The results were given as trolox equivalent.

\subsection{Statistical Analysis}

Analysis of all parameters in the oil samples was performed in triplicate. Statistica 9.0 StatSoft was used to analyse the data. One-way ANOVA with the HSD Tukey test was used to evaluate the significant inter-mean differences at $p<0.05$. A dendrogram was obtained by hierarchical cluster analysis, considering the numerical data for all parameters described in Table 6, using the Euclidean distances between individual data points.

\section{Conclusions}

Chemical characteristics and antioxidant properties of oils from eight cultivars of sour cherries grown in Poland were analysed in this study. The results revealed that sour cherry kernels contained appreciable amounts of oil rich in several classes of pharmacological active compounds with known therapeutic uses. As a high oleic-linoleic oil, it can be extremely important for human health due to its superior stability and nutritional value. Moreover, the presence of bioactive compounds, such as tocopherols, carotenoids, and polyphenols in sour cherry kernel oils, demonstrates the possibility of their further applications in cosmetics and pharmaceuticals offering health benefits.

Author Contributions: Conceptualization, M.S., A.K.-D. and M.M.; methodology, M.S. and A.K.-D.; software, A.K.-D. and M.M.; validation, M.S., A.K.-D. and M.M.; formal analysis, M.S.; investigation, A.K.-D. and M.M.; resources, M.M. and A.K.-D.; data curation, M.S., A.K.-D. and M.M.; writingoriginal draft preparation, M.M.; writing-review and editing, A.K.-D. and M.M.; visualization, A.K.-D. and M.M.; supervision, J.C.; project administration, A.K.-D.; funding acquisition, M.S. and J.C. All authors have read and agreed to the published version of the manuscript.

Funding: This research was funded by State School of Higher Education in Chełm.

Institutional Review Board Statement: Not applicable.

Informed Consent Statement: Not applicable.

Data Availability Statement: The data presented in this study are available on request from the corresponding authors.

Conflicts of Interest: The authors declare no conflict of interest. The funders had no role in the design of the study; in the collection, analyses, or interpretation of data; in the writing of the manuscript, or in the decision to publish the results.

Sample Availability: Samples of oils are available from the authors.

\section{References}

1. Zhou, Y.; Zhao, W.; Lai, Y.; Zhang, B.; Zhang, D. Edible Plant Oil: Global Status, Health Issues, and Perspectives. Front. Plant Sci. 2020, 11, 1315. [CrossRef] [PubMed]

2. Proietti, S.; Moscatello, S.; Villani, F.; Mecucci, F.; Walker, R.P.; Famiani, F.; Battistelli, A. Quality and nutritional compounds of Prunus cerasus L. var. austera fruit grown in central Italy. Hortiscience 2019, 54, 1005-1012. [CrossRef]

3. Michalak, M.; Kiełtyka-Dadasiewicz, A. Oils from fruit seeds and their dietetic and cosmetic significance. Herba Pol. 2018, 64, 63-70. [CrossRef] 
4. Dhavamani, S.; Rao, Y.P.C.; Lokesh, B.R. Total antioxidant activity of selected vegetable oils and their influence on total antioxidant values in vivo: A photochemiluminescence based analysis. Food Chem. 2014, 164, 551-555. [CrossRef]

5. Matthäus, B.; Özcan, M.M. Fatty acids and tocopherol contents of some Prunus spp. kernel oils. J. Food. Lipids 2009, 16, 187-199. [CrossRef]

6. Kazempour-Samak, M.; Rashidi, L.; Ghavami, M.; Sharifan, A.; Hosseini, F. Sour cherry (Cerasus vulgaris Miller) kernel oil as the novel functional edible oil: Sensory evaluation and antioxidant and physicochemical properties. J. Food Qual. 2021, 11, 5529613. [CrossRef]

7. Górnaś, P.; Rudzińska, M.; Raczyk, M.; Mišina, I.; Soliven, A.; Seglina, D. Composition of bioactive compounds in kernel oils recovered from sour cherry (Prunus cerasus L.) by-products: Impact of the cultivar on potential applications. Ind. Crops Prod. 2016, 82, 44-50. [CrossRef]

8. Bak, I.; Lekli, I.; Juhasz, B.; Varga, E.; Varga, B.; Gesztelyi, R.; Tosaki, A. Isolation and analysis of bioactive constituents of sour cherry (Prunus cerasus) seed kernel: An emerging functional food. J. Med. Food 2010, 13, 905-910. [CrossRef] [PubMed]

9. Popa, V.M.; Misca, C.; Bordean, D.; Raba, D.N.; Stef, D.; Dumbrava, D. Characterization of sour cherries (Prunus cerasus) kernel oil cultivars from Banat. J. Agroaliment. Processes Technol. 2011, 17, 398-401.

10. Lazos, E.S. Composition and oil characteristics of apricot, peach and cherry kernel. Grasas Aceites 1999, 42, 127-131. [CrossRef]

11. Yılmaz, C.; Gökmen, V. Compositional characteristics of sour cherry kernel and its oil as influenced by different extraction and roasting conditions. Ind. Crops Prod. 2013, 49, 130-135. [CrossRef]

12. Uluata, S.; Özdemir, N. Evaluation of chemical characterization, antioxidant activity and oxidative stability of some waste seed oil. Turk. J. Food Agric. Sci. 2017, 5, 48-53. [CrossRef]

13. Chandra, A.; Nair, M.G. Characterization of pit oil from Montmorency cherry (Prunus cerasus L.). J. Agric. Food Chem. 1993, 41, 879-881. [CrossRef]

14. Faostat "Crops" Countries-Poland; Elements-Production Quantity; Items-Cherries, Sour. 2018. Available online: http://www. fao.org/faostat/en/\#data/QC/ (accessed on 10 January 2022).

15. Codex Alimentarius Commission; FAO/WHO Food Standards Programme. Fats, Oils and Related Products, 2nd ed.; Codex Alimentarius Commission: Rome, Italy, 2001.

16. Aqil, Y.; Ouassor, I.; Belmaghraoui, W.; El Hajjaji, S. Prunus avium kernel oil characterization: A comparative study of four varieties from Sefrou, Morocco. OCL 2020, 27, 4. [CrossRef]

17. Korlesky, N.M.; Stolp, L.J.; Kodali, D.R.; Goldschmidt, R.; Byrdwell, W.C. Extraction and characterization of Montmorency sour cherry (Prunus cerasus L.) pit oil. J. Am. Oil Chem. Soc. 2016, 93, 995-1005. [CrossRef]

18. Ponnampalam, E.N.; Sinclair, A.J.; Holman, B.W.B. The Sources, Synthesis and Biological Actions of Omega-3 and Omega-6 Fatty Acids in Red Meat: An Overview. Foods 2021, 10, 1358. [CrossRef] [PubMed]

19. Michalak, M.; Pierzak, M.; Kręcisz, B.; Suliga, E. Bioactive compounds for skin health: A review. Nutrients 2021, 13, 203. [CrossRef]

20. Mihai, A.L.; Negoiţă, M.; Horneţ, G.A. Nutritional potential of some cold pressed vegetable oils in terms of fatty acids. CTNS 2020, 9, 104-116. [CrossRef]

21. Ibourki, M.; Azouguigh, F.; Jadouali, S.M.; Sakar, E.H.; Bijla, L.; Majourhat, K.; Gharby, S.; Laknifli, A. Physical Fruit Traits, Nutritional Composition, and Seed Oil Fatty Acids Profiling in the Main Date Palm (Phoenix dactylifera L.) Varieties Grown in Morocco. J. Food Qual. 2021, 11, 5138043. [CrossRef]

22. Stryjecka, M.; Kiełtyka-Dadasiewicz, A.; Michalak, M.; Rachoń, L.; Głowacka, A. Chemical Composition and Antioxidant Properties of Oils from the Seeds of Five Apricot (Prunus armeniaca L.) Cultivars. J. Oleo Sci. 2019, 68, 729-738. [CrossRef]

23. Hajib, A.; Nounah, I.; Harhar, H.; Gharby, S.; Kartah, B.; Matthäus, B.; Bougrin, K.; Charrouf, Z. Oil content, lipid profiling and oxidative stability of "Sefri" Moroccan pomegranate (Punica granatum L.) seed oil. OCL 2021, 28, 2020069. [CrossRef]

24. Nounah, I.; Gharby, S.; Hajib, A.; Harhar, H.; Matthäus, B.; Charrouf, Z. Effect of seeds roasting time on physicochemical properties, oxidative stability, and antioxidant activity of cactus (Opuntia ficus-indica L.) seed oil. Food Process. Preserv. 2021, 11, 15747. [CrossRef]

25. Łoźna, K.; Kita, A.; Styczyńska, M.; Biernat, J. Fatty acid composition of oils recommended in the prevention of lifestyle diseases. Probl. Hig. Epid. 2012, 93, 871-875.

26. Sakar, E.H.; El Yamani, M.; Boussakouran, A.; Ainane, A.; Ainane, T.; Gharby, S.; Rharrabti, Y. Variability of oil content and its physicochemical traits from the main almond [Prunus dulcis Mill. DA Webb] cultivars grown under contrasting environments in north-eastern Morocco. Biocatal. Agric. Biotechnol. 2021, 32, 101952. [CrossRef]

27. Sales-Campos, H.; Reis de Souza, P.; Crema Peghini, B.; da Silva, J.S.; Ribeiro Cardoso, C. An overview of the modulatory effects of oleic acid in health and disease. Mini-Rev. Med. Chem. 2013, 13, 201-210. [CrossRef] [PubMed]

28. Marangoni, F.; Agostoni, C.; Borghi, C.; Catapano, A.L.; Cena, H.; Ghiselli, A.; La Vecchia, C.; Lercker, G.; Manzato, E.; Pirillo, A.; et al. Dietary linoleic acid and human health: Focus on cardiovascular and cardiometabolic effects. Atherosclerosis 2020, 292, 90-98. [CrossRef] [PubMed]

29. Vicanova, J.; Ponec, M.; Weerheim, A.; Swope, V.; Westbrook, M.; Harriger, D.; Boyce, S. Epidermal lipid metabolism of cultured skin substitutes during healing of full-thickness wounds in athymic mice. Wound Repair Regen. 1997, 5, 329-338. [CrossRef]

30. Ogbe, R.J.; Ochalefu, D.O.; Mafulul, S.G.; Olaniru, O.B. A review on dietary phytosterols: Their occurrence, metabolism and health benefits. Asian J. Plant Sci. Res. 2015, 5, 10-21. 
31. Micera, M.; Botto, A.; Geddo, F.; Antoniotti, S.; Bertea, C.M.; Levi, R.; Gallo, M.P.; Querio, G. Squalene: More than a step toward sterols. Antioxidants 2020, 9, 688. [CrossRef] [PubMed]

32. Huang, Z.R.; Lin, Y.K.; Fang, J.Y. Biological and pharmacological activities of squalene and related compounds: Potential uses in cosmetic dermatology. Molecules 2009, 14, 540-554. [CrossRef] [PubMed]

33. Berganza, B.E.; Moran, A.W.; Rodriguez, G.; Coto, N.M.; Santamaria, M.; Bressani, R. Effect of variety and location on the total fat, fatty acids and squalene content of amaranth. Plant Food Hum. Nutr. 2003, 58, 24454. [CrossRef]

34. Rizvi, S.; Raza, S.T.; Ahmed, F.; Ahmad, A.; Abbas, S.; Mahdi, F. The role of vitamin E in human health and some diseases. Sultan Qaboos Univ. Med. J. 2014, 14, 157-165.

35. Hensley, K.; Benaksas, E.J.; Bolli, R.; Comp, P.; Grammas, P.; Hamdheydari, L.; Mou, S.; Pye, Q.N.; Stoddard, M.F.; Wallis, G.; et al. New perspectives on vitamin E: $\gamma$-tocopherol and carboxyethylhydroxychroman metabolites in biology and medicine. Free Rad. Biol. Med. 2004, 36, 1-15. [PubMed]

36. AOAC Official Method 2003.05 Crude Fat in Feeds, Cereal Grains, and Forages. Available online: https://www.eoma.aoac.org/ (accessed on 20 January 2022).

37. ISO 5983-1:2005; Animal Feeding Stuffs-Determination of Nitrogen Content and Calculation of Crude Protein Content-Part 1: Kjeldahl Method. Available online: https:/ / www.iso.org/standard/39145.html (accessed on 20 January 2022).

38. ISO 3657:2013; Animal and Vegetable Fats and Oils—Determination of Saponification Value. Available online: https://www.iso. org/standard / 60526.html (accessed on 20 January 2022).

39. ISO 3960:2007; Animal and Vegetable Fats and Oils-Determination of Peroxide Value. Available online: https://www.iso.org/ standard/39158.html (accessed on 20 January 2022).

40. ISO 660:2009; Animal and Vegetable Fats and Oils-Determination of Acid Value and Acidity. Available online: https://www.iso. org/standard / 44879.html (accessed on 20 January 2022).

41. ISO 3961:2009; Animal and Vegetable Fats and Oils-Determination of Iodine Value. Available online: https://www.iso.org/ standard/46136.html (accessed on 20 January 2022).

42. ISO 5509:2000; Animal and Vegetable Fats and Oils-Preparation of Methyl Esters of Fatty Acids. Available online: https: / / www.iso.org/standard/11560.html (accessed on 20 January 2022).

43. ISO 5508:1990; Animal and Vegetable Fats and Oils-Analysis by Gas Chromatography of Methyl Esters of Fatty Acids. Available online: https: / / www.iso.org/standard/11558.html (accessed on 20 January 2022).

44. PN-EN 12822:2014-08; Foodstuffs-Determination of Vitamin E by High Performance Liquid Chromatography-Measurement of $\alpha-, \beta-, \gamma-$ and $\delta$-tocopherol. Available online: https://standards.iteh.ai/catalog/standards/cen/19f43eeb-e978-44a9-b5a6-362ac2 6c9bb6/en-12822-2000 (accessed on 20 January 2022).

45. Singleton, V.L.; Rossi, J.A. Colorimetry of total phenolics with phosphomolybdic-phosphotungstic acid reagents. Am. J. Enol. Vitic. 1965, 16, 144-158.

46. Szydłowska-Czerniak, A.; Karlovits, G.; Dianoczki, C.; Recseg, K.; Szłyk, E. Comparison of two analytical methods for assessing antioxidant capacity of rapeseed and olive oils. J. Am. Oil Chem. Soc. 2008, 85, 141-149. [CrossRef]

47. Singh, R.P.; Murthy, K.N.C.; Jayaprakasha, G.K. Studies on the antioxidant activity of pomegranate (Punica granatum) peel and seed extracts using in vitro models. J. Agric. Food Chem. 2002, 50, 81-86. [CrossRef]

48. Re, R.; Pellegrini, N.; Proteggente, A.; Pannala, A.; Yang, M.; Rice-Evans, C. Antioxidant activity applying an improved ABTS radical cation decolarization assay. Free Radic. Biol. Med. 1999, 26, 1231-1237. [CrossRef] 